\title{
Stem cell therapies for spinal cord injury
}

\author{
Vibhu Sahni and \\ MGH-HMS Center for Nervous System Repair, Harvard Medical School, 50 Blossom Street, \\ Boston, MA 02114, USA.
}

John A. Kessler

Department of Neurology, Feinberg School of Medicine, Northwestern University, 303 East

Chicago Avenue, Chicago, IL 60611-3008, USA.

\begin{abstract}
Stem cell therapy is a potential treatment for spinal cord injury (SCI), and a variety of different stem cell types have been evaluated in animal models and humans with SCI. No consensus exists regarding the type of stem cell, if any, that will prove to be effective therapeutically. Most data suggest that no single therapy will be sufficient to overcome all the biological complications caused by SCI. Rationales for therapeutic use of stem cells for SCI include replacement of damaged neurons and glial cells, secretion of trophic factors, regulation of gliosis and scar formation, prevention of cyst formation, and enhancement of axon elongation. Most therapeutic approaches that use stem cells involve implantation of these cells into the spinal cord. The attendant risks of stem cell therapy for SCI-including tumor formation, or abnormal circuit formation leading to dysfunction-must be weighed against the potential benefits of this approach. This Review will examine the biological effects of SCI, the opportunities for stem cell treatment, and the types of stem cells that might be used therapeutically. The limited information available on the possible benefits of stem cell therapy to humans will also be discussed.
\end{abstract}

\section{Introduction}

Spinal cord injury (SCI) occurs with a worldwide annual incidence of 15-40 cases per million people. ${ }^{1,2}$ in the us alone, acute SCI affects 12,000 individuals annually-4,000 of these patients die before reaching hospital and another 1,000 die during their hospitalization. ${ }^{3}$ These data, however, considerably underestimate the prevalence and societal impact of SCI. A 2004 study sponsored by the Christopher and Dana Reeve Foundation revealed that $1,275,000$ people in the US have some form of SCI-more than five times the number of Americans previously estimated in 2007 (255,702) - and SCI costs the health system an estimated US $\$ 40.5$ billion annually. ${ }^{4}$ Depending on the severity and location of the injury, patients present with a range of functional impairments, including sensory, motor and autonomic dysfunction, arising from both the damage to the local circuitry of the spinal cord and the disruption of the ascending and descending fiber tracts. ${ }^{5}$

The word 'stem cell' has generally been used to describe a cell that can divide, give rise to more stem cells, and produce progeny that can then differentiate into mature cell types, although different kinds of stem cells have shown differing capacities in these regards. Stem cells have now been identified in several organ systems in the embryo, as well as in the

(C) 2010 Macmillan Publishers Limited. All rights reserved

Correspondence to: J. A. Kessler jakessler@northwestern.edu.

Competing interests

The authors declare no competing interests. 
adult. Many different types of stem cell, including embryonic stem cells, various types of neural stem cell, and stem cells from non-neural tissues such as hematopoieitic stem cells, have been transplanted into the spinal cord after SCI, with the goal of promoting repair and recovery from the injury.

This Review builds on several excellent reviews in the field and will consider issues regarding recovery from SCI and the potential for stem cell therapy as a treatment for this injury. We will discuss the cellular events that occur following SCI, evaluate the role of stem cell therapy in SCI, and cover some of the clinical trials that aim to translate laboratory stem cell research into clinical practice.

\section{Spinal cord injury-cellular response}

The cellular and molecular events that occur in response to SCI have been studied in a variety of different animal models. Transection lesions in animal models are reproducible, but their clinical relevance is questionable because they do not mimic the vast majority of SCIs in humans, namely, crush injuries. Contusion and crush models in animals, however, do produce a histological picture that resembles the typical pathology of SCI in humans.

In both rodent and human SCI, contusion of the spinal cord induces direct damage resulting from membrane disruption, vascular damage and hemorrhage. The final pathological picture, however, greatly exceeds the damage identified in the first few hours after injury, because secondary injury processes are activated. ${ }^{6-8}$ A study in rats shows that near the center of the injury, a spared rim of tissue and axons typically remains at the periphery of the lesion. ${ }^{9}$ This spared rim of axons has also been observed in SCI in humans, even in patients with neurologically complete SCI. ${ }^{10}$ An active process of programmed cell death (apoptosis) also increases the secondary damage after trauma to the spinal cord, and apoptosis in rodents with an injured spinal cord continues for weeks after the initial trauma. ${ }^{11}$ Spinal neurons typically succumb-mostly to necrosis or excitotoxic damage, but also occasionally to apoptosis-within $24 \mathrm{~h}$ after SCI. By constrast, oligodendrocytes undergo apoptosis in two distinct phases: an early acute phase lasting for the first $24-48 \mathrm{~h}$ and a later subacute phase that can last up to several weeks after the assault. ${ }^{11}$ Similar patterns of cell death are observed in SCI in primates ${ }^{12}$ and humans. ${ }^{13} \mathrm{~A}$ major goal for the therapeutic use of stem cells is to prevent apoptosis or to replace lost cells, particularly oligodendrocytes, which could facilitate the remyelination of spared axons.

Another consequence of SCI is formation of a glial scar that impedes axon regeneration. Inhibition of glial scar formation is another important target for stem cell therapies. After CNS damage, astrocytes respond with a characteristic hypertrophic response accompanied by an increase in the production of intermediate filaments such as glial fibrillary acidic protein-a process termed reactive astrocytosis or astrogliosis. ${ }^{14}$ In time, more cell types, including microglia, macrophages, leptomeningeal cells and dividing progenitor cells, are recruited, culminating in the formation of the glial scar. This structure poses a problem for axon regeneration: it acts as a physical barrier and accumulates molecules that inhibit axon outgrowth, such as chondroitin sulfate proteoglycan (CSPG). ${ }^{15,16}$ Enzymatic removal of the GAG side chains from CSPG promotes axon growth after traumatic CNS injury in vivo. ${ }^{17}$ Several theories have been proposed to describe the molecular mechanisms by which CSPGs inhibit axon regeneration. ${ }^{18-21}$ In 2009, a receptor for CSPG was identified, the antagonism of which enabled increased axon outgrowth following SCI. ${ }^{22}$ Strategies that reduce the overall extent of the glial scar ${ }^{23,24}$ or diminish its inhibitory effects ${ }^{25}$ could, therefore, be used to support axon regeneration. Reactive astrocytes also have a beneficial role in the early acute stages after SCI. These cells limit the infiltration of inflammatory cells through the blood-brain barrier and also facilitate repair of this barrier, thereby re- 
establishing homeostasis and restricting tissue damage. ${ }^{26-29}$ Strategies that inhibit astrocytosis too early might, therefore, cause more harm than good.

CNS injury also has a strong immune component. ${ }^{30,31}$ Damage to the blood-brain barrier leads to invasion by peripheral immune cells (for example, lymphocytes and macrophages) and microglia, which might con tribute to the secondary damage seen in SCI by increasing both apoptosis and necrosis. ${ }^{30,31}$ Whether microglia are beneficial or detrimental to recovery from SCI is unclear. Microglial cells undergo several morphological changes during activation following CNS injury ${ }^{32}$ and may produce molecules such as the proform of nerve growth factor that cause apoptosis of oligodendrocytes, ${ }^{33}$ thereby contributing to demyelination and dysfunction of spared axons after partial SCI. Furthermore, myelin breakdown products, such as reticulon-4 (also known as neurite outgrowth inhibitor or Nogo) and myelin-associated glycoprotein, are potent inhibitors of axon outgrowth. ${ }^{34}$ Additional therapeutic strategies have, therefore, focused on modulating the immune response and on blocking the effects of such inhibitory molecules. For example, transplantation of autologous macrophages, activated ex vivo by peripheral myelin, promoted functional recovery in paraplegic rats when injected into the experimentally injured spinal cord. ${ }^{35}$

\section{Stem cells and spinal cord injury}

Stem cells have three fundamental properties: high proliferative potential, self-renewal by means of asymmetric cell division - production of one daughter cell identical to the mother cell and another cell that progresses down an alternative differentiation pathway-which maintains the 'stem cell niche', and the ability to differen tiate into multiple cell types. Profound differences exist between stem cells with respect to the types of cells that they can generate. Stem cells that are capable of generating an entire organism are termed totipotent; a good example is a fertilized egg. Stem cells that can give rise to lineages derived from all the three primary germ layers - namely ectoderm, mesoderm and endoderm-are termed pluripotent, an example being embryonic stem (ES) cells. Multipotent stem cells are cells that can give rise to multiple cell types within a germ layer; since adult as well as embryonic organs all contain multipotent stem cells, these cells are often called adult stem cells in the lay literature. The term progenitor cell is sometimes used interchangeably with stem cell, but in this Review the term will be used to describe cells that have a finite proliferative capacity and a limited differentiation potential.

Therapeutic strategies involving transplantation of stem cells after SCI focus on the replacement of lost or damaged cells (mainly neurons and oligodendrocytes), provision of trophic support for neurons, or manipulation of the environment within the damaged spinal cord to facilitate axon regeneration. Many different types of stem and progenitor cells have been transplanted into injured spinal cords, the main goal being to promote recovery. ${ }^{36-42}$ In the sections that follow, we review the rationales for stem cell-based approaches that have had some success in animal models of SCI, and discuss their potential for clinical application (Figure 1).

\section{Cell replacement}

Replacement of lost or damaged neurons, or of oligodendrocytes to facilitate myelination of spared axons, is an important goal of stem cell transplantation (Figure 1a,b). ${ }^{43} \mathrm{SCI}$ has largely been viewed as a predominantly 'white matter problem', but evidence is emerging that demonstrates the need to replenish neuronal populations within the gray matter of the spinal cord (motor neurons and interneurons) to repair intraspinal circuitry and improve functional recovery (reviewed elsewhere ${ }^{44}$ ). This task is challenging, however, because, 
unlike other regions in the adult mammalian nervous system, the spinal cord does not possess a neurogenic niche. ${ }^{45,46}$

Pluripotent ES cells are derived from the inner cell mass of developing blastocysts. ${ }^{49-51}$ The pluripotency and possibility of virtually unlimited expansion of ES cells make them attractive as a source of cells for transplantation into the injured spinal cord. ES cells would form teratomas if transplanted in an undifferentiated form, so protocols have been developed to differentiate these cells into specific neuronal lineages (for example, dopaminergic cells $^{47,48}$ or motor neurons ${ }^{49,50}$ ) and glial lineages before transplantation. 51 'Neuralized' mouse ES cells transplanted into the injured spinal cord of a rat survived, differentiated into multiple lineages, and contributed to partial functional recovery. ${ }^{52} \mathrm{ES}$ cells predifferentiated into oligodendrocyte progenitor cells ${ }^{51,53}$ subsequently differentiated into mature oligodendrocytes, thereby remyelinating spared axons and improving locomotor function, when transplanted into the injured rat spinal cord 7 days after SCI. ${ }^{54,55}$ Notably, ES cells have been shown to have therapeutic benefits only when transplanted into experimental models of mild to moderately severe SCI. These cells show little benefit when transplanted into the severely injured human spinal cord—an important issue when evaluating potential clinical uses for stem cell therapy.

Multipotent progenitor cells from the fetal or adult CNS or other tissues have also been employed in experimental SCI. These cells are predetermined to differentiate specifically into neural lineages, although their differentiation potential can vary depending on the specific cell type. For example, multipotent neural progenitor cells are capable of differentiating into neurons, astrocytes and oligo dendrocytes, whereas glial pro genitor cells are committed to differentiate into macroglia but not neurons. Transplanted multipotent cells typically differen tiate into astrocytes, and only a small subset give rise to neurons or oligodendrocytes, ${ }^{36,56-59}$ with some functional improvement being observed in these latter instances. Some studies have circumvented this issue by transplanting neuronal lineagerestricted precursor cells into the injured spinal cord. These cells lack the ability to differentiate into glia (unlike the multipotent cells described earlier) and, after transplantation, differentiate exclusively into neurons. ${ }^{60,61}$ Neuronal replacement and integration by means of fetal grafts, ${ }^{62,63}$ pluripotent cells predifferentiated into specific neuronal lineages such as motor neurons, ${ }^{64,65}$ or progenitor cells in combination with neurotrophins to promote directional growth, have been attempted in animal models of SCI. ${ }^{66}$ Transplantation of glial progenitor cells in combination with neurotrophins (neurotrophin-3 and brain-derived neurotrophic factor [BDNF]) has been shown to promote functional recovery in a rat model of contusive SCI. ${ }^{67}$ The effects of transplanted cells depend on the conditions under which they were cultured. For example, astrocytes derived from glial progenitor cells in the presence of specific growth factors, such as bone morphogenetic protein 4 , exert beneficial effects in experimental models of SCI. ${ }^{68}$ The limited availability of multipotent neural progenitor cells and the restricted range of cell types that they generate in the injured spinal cord could limit their clinical utility.

Studies have described transplantation of stem cells from non-neural tissues (bone marrow, umbilical cord, blood or skin) into the injured spinal cord in animal models, ${ }^{38}$ and bonemarrow derived cells have also been tried in patients with SCI. ${ }^{69}$ The initial rationale for transplanting bone marrow-derived cells was based on reports that these cells have the potential to generate neurons and glial cells. ${ }^{70,71}$ This evidence for transdifferentiation-a process by which cells of one organ lineage generate cell types from different organssuggested that damaged cells could be replaced using such bone marrow-derived grafts. These grafts have the additional advantage of being autologous, thereby avoiding possible graft rejection. Most reports, however, did not actually reflect 'true' transdifferentiation, with many factors, such as the presence of contaminating cells, persistence of primitive 
cells, cell fusion, or gene transfer, confounding the results. ${ }^{72}$ The prospect of transdifferentiation occurring at high enough rates to contribute toward cell replacement seems unlikely. ${ }^{72}$ Studies report functional improvements after this type of stem cell transplantation in experimental models of SCI, ${ }^{38}$ but clinical trials with this approach have not produced any significant functional recovery.

\section{Neuroprotection and trophic support}

Transplanted stem cells can provide trophic support to promote survival of host cells at the lesion site, and to prevent atrophy and loss of projection neurons that reside at distant locations but have axons that traverse the lesion, such as midbrain rubrospinal neurons (Figure 1c,d). ${ }^{73}$ Transplanted cells can be genetically modified ${ }^{74}$ to produce neurotrophic factors for these purposes. ${ }^{75}$ Intriguingly, a suggestion has been made that such genetically modified transplanted cells can alter the responses of endogenous progenitor cells (see below). Whether reported successes in experimental SCI have arisen from these mechanisms alone or in combination has been difficult to establish.

\section{Facilitating axon regeneration}

Traditionally, axons of the mammalian PNS were believed to regenerate following injury, whereas axons in the injured CNS were thought not to regenerate. ${ }^{76}$ Transplantation of a peripheral nerve graft into the injured rat spinal cord, however, resulted in robust outgrowth of the damaged CNS axons into the graft, ${ }^{77}$ even in the chronically injured spinal cord. ${ }^{78}$ This research suggested that failure of CNS regeneration largely reflects the inhospitable environment of the injured spinal cord rather than a limitation in growth of the axons; injured CNS axons that regenerate into a peripheral nerve graft do not grow past the graft into the host CNS environment. Regeneration of CNS neurons into a peripheral nerve graft has also been observed in the spinal cords of primates. ${ }^{79}$ The lesion site is known to contain several inhibitors of axon outgrowth, such as CSPGs, on reactive astrocytes that form the glial scar,,${ }^{15,80}$ on the myelin in the CNS, ${ }^{34}$ or in other cell types that are involved in the formation of the glial scar. ${ }^{15}$

Numerous studies have examined transplantation of different cell types to create a permissive environment for axon regeneration (Figure 1e,f). Reportedly successful approaches in experimental SCI have used Schwann cell grafts ${ }^{81,82}$ or olfactory ensheathing cells for transplantation. ${ }^{83}$ This success did not, however, translate to studies using similar strategies in humans. ${ }^{84,85} \mathrm{In}$ addition, stem cells from non-neural lineages, such as marrow stromal cells, have been used to fill lesion cavities and to act as permissive substrates for axon outgrowth in animal models. ${ }^{86,87}$ These cells can be easily derived and expanded in vitro, which makes them good candidates for autologous grafts in human patients.

As noted previously, transplanted cells can be genetically modified ${ }^{74}$ to produce neurotrophic factors that can, in turn, promote axonal outgrowth. ${ }^{88,89}$ Combination therapies in which transplants of either marrow stromal cells or neural progenitor cells were combined with neurotrophic factor treatments, or with other approaches that increase the growth potential of neurons, have been partially successful in promoting sensory 90,91 and motor axon $^{92}$ regeneration. Such combination therapies can enhance sensory axon regeneration even in models of the chronically injured spinal cord. ${ }^{93}$

\section{Stem cell therapy-from bench to clinic}

Successes with stem cell transplantation in experimental SCI have been notable but limited, and caution must be exercised in translating successes in the research laboratory to clinical use (Box 1) ${ }^{94}$ In addition, the International Campaign for Cures of Spinal Cord Injury 
Paralysis has now set guidelines for the conduct and ethics of clinical trials on stem cell therapy for SCI. These guidelines include recommendations on how clinical trials should measure outcome, the issue of spontaneous recovery, clinical trial design, the inclusion and exclusion criteria used in clinical trials, and the importance of ethics in clinical trials. ${ }^{95-98}$

\section{Clinical trials}

The field of stem cell therapy is in its relative infancy, so decisions regarding therapeutic applications must be made with caution and prudence. Widespread optimism in the public sphere regarding this issue also brings the problem of setting unrealistic expectations. ${ }^{99}$ Premature clinical trials of stem cell therapy carry the risk of creating more harm than benefit. Furthermore, any negative outcome or serious adverse effects could potentially damage the long-term development of the field. Many uncontrolled and scientifically dubious stem cell 'therapies' have been offered worldwide for SCI with little or no rationale in many cases. ${ }^{100}$ However, several well-controlled studies have been initiated on the basis of the successes of strategies in early rodent studies that aimed to create a hospitable environment for regeneration of the spinal cord. So far, little evidence has been obtained of clinically significant benefits. Marginal indications of efficacy have been reported in some studies, but no stem cell therapies are yet approved for SCI. We now briefly describe some of the clinical trials of stem cell-based and other cell transplantation strategies for the treatment of SCI (Table 1). ${ }^{101,102}$

Geffner et al. ${ }^{103}$ investigated the administration of bone marrow stem cells into eight patients with SCI (four acute and four chronic). Cells were administered via multiple routes - directly into the spinal cord, directly into the spinal canal, and intravenously-and patients were followed up for 2 years. Some improvements in Asia Spinal Injury Association (ASIA), Barthel (quality of life), Frankel and Ashworth scores were observed, as well as possible improvements in bladder function and changes in spinal cord appearance on MRI. ${ }^{103}$ The authors stated that they administered stem cells to a total of 52 patients with SCI (including those described above), and they did not observe marked adverse effects. Other groups have tested the safety of transplantation of bone marrow-derived cells in patients with SCI, and all indicate that administration of these cells does not cause any adverse effects. ${ }^{69,104}$ In addition, Yoon et al. ${ }^{105}$ studied the effects of autologous human bone marrow cell transplantation in combination with administration of granulocytemacrophage colony-stimulating factor to 35 patients with complete SCI. Bone marrow cells were transplanted by injection into the area surrounding the lesion in acute, subacute and chronic injuries, and no serious complications were reported. ${ }^{105}$

To assess the feasibility and safety of autologous olfactory ensheathing cells, Feron et al. ${ }^{84}$ performed a single-blind phase I clinical trial in which three patients with paraplegia (chronic and stable injuries) received these cells 6-32 months after their spinal injury. No medical, surgical or other complications were reported 1 year after cell implantation. Furthermore, no evidence of spinal cord damage; cyst, syrinx or tumor formation; neuropathic pain; change in psychosocial status; or deterioration in neurological status was observed. ${ }^{84}$ The same investigators then followed up six patients with SCI (including three patients who did not receive transplants and, therefore, acted as controls) for 3 years after cell transplantation. ${ }^{106}$ Using testing for neuro logical and functional deficits (the standard ASIA scale and the Functional Independence Measure), and medical, psychosocial, radiological and neurological assessments, the investigators found no evidence of clinical efficacy. ${ }^{106}$ By contrast, in a relatively uncontrolled study, Lima et al. ${ }^{107}$ reported beneficial effects from the transplantation of olfactory mucosa autografts in patients with chronic SCI when this cell transplant was combined with postoperative rehabilitation. ${ }^{107}$ 
Saberi and colleagues ${ }^{85}$ purified Schwann cells from the sural nerves of four patients with stable, chronic midthoracic SCI. Schwann cell cultures were grown without any mitogenic or growth factors and then transplanted into the injured spinal cord 28-80 months after the spinal injury. Patients were evaluated for 1 year after transplantation using the ASIA scale criteria and MRI, and were also assessed for sphincter and sexual function. No adverse effects from Schwann cell transplantation were reported. ${ }^{85}$ Of the four patients studied, only one patient with incomplete SCI showed improvements in motor and sensory functions 1 year after receiving cell transplantation combined with extensive and continuous rehabilitation. All four patients experienced transient paresthesisas or increased muscle spasm after Schwann cell transplantation, but MRI did not reveal any obvious pathological changes in the spinal cord after 1 year. ${ }^{85}$

Transplantation of activated autologous macrophages formed the basis of one of the first carefully designed, rigorous clinical trials in the field. In the initial phase I trial, eight patients with complete SCI underwent transplantation of autologous macrophages that were isolated from the patients' blood and incubated with excised skin - a procedure termed 'ProCord' developed by Proneuron Biotechnologies (New York, NY, USA)—within 14 days of injury. Three of the eight patients showed some recovery, and no major adverse events were reported. ${ }^{108} \mathrm{~A}$ subsequent multicenter phase II ProCord trial in Israel and the US was suspended prematurely in 2006 for financial reasons, with no current plans to continue this study.

Moviglia et al. ${ }^{109}$ reported preliminary successes using a combination of neurorehabilitation and cell transplants in two patients with paraplegia (aged 19 and 21 years). ${ }^{109}$ The participants received their own $\mathrm{T}$ cells intravenously, followed by transplantation to the lesion site, via a feeding artery, of their own marrow stromal cells that had previously been cocultured with their T cells. ${ }^{109}$ This approach attempted to generate a controlled inflammatory response at the injury site in preparation for the stem cell transplantation. Given the small number of patients in this study, the validity of these results is difficult to assess. ${ }^{109}$

A large clinical trial is underway in China involving transplantation of mononuclear cells derived from umbilical cord blood, which includes a population of stem cells. Cells are being injected bilaterally into the entry zone of the dorsal root, both above and below the injury site. No results from this trial have yet been published. ${ }^{110}$ The Spinal Cord Injury Network USA ${ }^{111}$ is also planning a study of umbilical cord blood mononuclear cell transplants combined with lithium treatment in people with chronic traumatic SCI.

\section{Commercial development}

The biotechnology industry has made a concerted effort to develop and provide stem cellbased therapeutics for neurological disorders. For example, Q Therapeutics (Salt Lake City, UT, USA) has proposed treatment with glial progenitor cells for remyelination. Neuralstem (Rockville, MD, USA) has developed technologies to isolate and grow neural stem cells from diverse regions of the developing human brain and spinal cord. The involvement of biotechnology companies brings the notable advantage of resources-financial, intellectual and manpower-to accelerate progress, and the development of several new lines of human neuralized stem cells can only be regarded favorably. The engagement of such for-profit ventures does, however, raise the possibility that vested interests could trump SCIentific and ethical concerns.

Geron (Menlo Park, CA, USA) has requested permission from the FDA to conduct a trial evaluating human ES cell-derived oligodendrocyte progenitor cell transplants in patients with a complete thoracic SCI, in the hope of myelinating spared axons. ${ }^{112,113}$ A legitimate 
concern is that the injuries that were first subjected to this approach in rodents were far less severe $^{54}$ than the ones in the human patients participating in the Geron clinical trial. In addition, residual undifferentiated stem cells could become proliferative and form tumors after transplantation, although the company has rigorously pursued techniques for preventing this eventuality. After initially approving the trial, the FDA put it on hold pending further evaluation of data regarding the formation of 'cysts' in animals that received transplants. Geron is now acquiring more preclinical data and hopes soon to begin trials in patients with cervical or thoracic SCI.

\section{Future strategies \\ Endogenous stem cells}

Stem and progenitor cells that are present in the adult CNS possess the capacity to proliferate and differentiate into subsets of neuronal and glial cell types. In the adult spinal cord, stem and progenitor cells in the ependymal zone possess the capacity to generate all major neural lineages, ${ }^{45,46}$ whereas progenitor cells scattered throughout the peripheral white matter seem to be limited to the generation of glial lineages. ${ }^{114}$ In rodents, SCI causes progenitor cell proliferation in both the white matter ${ }^{115}$ and the ependymal zone, ${ }^{116}$ but the endogenous progenitor cells differentiate exclusively into glia with no observable neuronal differentiation. ${ }^{42,46}$ Even progenitor cells that have the capacity to generate neurons in vitro only generate glia after transplantation into the injured spinal cord. ${ }^{117-119}$ Harnessing the potential of endogenous progenitor populations for SCI repair will require development of techniques for directing their commitment towards specific fates according to the desired function (for example, oligodendrocytes for remyelination, or new neurons for cell replacement ${ }^{42,120}$ ). Genetic manipulation of these progenitor cells (consisting of overexpression of either Neurogenin-2 or Mash1), along with growth factor treatments such as BDNF, was shown to direct differentiation towards neuronal or oligodendroglial fates. ${ }^{121}$

\section{Induced pluripotent stem cells}

In 2006, Takahashi et al. ${ }^{122}$ demonstrated that pluripotent cells could be derived from mouse fibroblasts by introducing four genes-PouSf1 (also known as Oct3/4), Sox2, Klf4 and c$M y c$ - into the cells via retrovirus-mediated gene transfer. ${ }^{122}$ The resulting cells, termed induced pluripotent stem cells (iPSCs), were not identical to ES cells but did demonstrate many of their characteristics, such as morphology, marker expression, and ability to form teratomas when injected into nude mice. ${ }^{122}$ This same phenomenon also occurs in human cells. ${ }^{123-125}$ Some genes that were used in this induction strategy, such as $c-M y c$, are known oncogenes. Since these transgenes had integrated into the genome of iPSCs, they could potentially be reactivated and result in tumor formation if these cells were transplanted into patients. Subsequently, iPSCs have been derived without using genetic alterations. Proteins that can reprogram cells are directly delivered to fibroblasts, thereby allaying concerns regarding oncogene reactivation and tumor formation. ${ }^{126}$

These advances have revolutionized the field of transplantation biology, raising the possibility of making patient-specific autologous stem cell lines that would eliminate the possibility of graft rejection. Furthermore, the iPSC approach bypasses the ethical issues that surround the use of human ES cells, although iPSCs seem to senesce more rapidly. ${ }^{127}$ Several groups have, collectively, made concerted efforts to differentiate iPSCs into different cell types to reverse disease in mouse models. This approach will require additional in-depth research before clinical trials can be initiated. ${ }^{128}$ 


\section{Conclusions}

SCI results in a multitude of changes affecting several different cell types, leading to a complex patho logical picture. Recovery from SCI will, therefore, require a multifaceted approach using a combination of different methodologies. Stem cell therapy is one strategy that offers potential for therapeutic use in both acute and chronic SCI. Different transplantation approaches have facilitated different aspects of recovery, and their final clinical use will most probably involve an amalgamation of all the various methods described in this review. Rodents provide a useful laboratory model to investigate the pathology of SCI and to evaluate therapeutic interventions after SCI. Though helpful, however, rodent models should not be the sole predictors of therapeutic success in humans. Caution must be exercised in translating successes in basic science research to clinical trials; several criteria, including severity and level of injury, therapeutic goal, and which type of cell to use, must be considered when developing these approaches for the clinic and in selecting appropriate volunteers for testing. with the advent of iPSCs, the prospect of generating patient-specific stem cell lines for transplantation purposes is exciting and has the potential to revolutionize regenerative medicine. In addition to transplanted stem cells, future approaches are likely to involve manipulation of endogenous stem cell populations within the spinal cord to promote recovery. More research on stem cell therapy for SCI is needed, but the overall future for this therapy looks promising.

\section{References}

1. Tator CH. Update on the pathophysiology and pathology of acute spinal cord injury. Brain Pathol. 1995; 5:407-413. [PubMed: 8974623]

2. Ackery A, Tator C, Krassioukov A. A global perspective on spinal cord injury epidemiology. J. Neurotrauma. 2004; 21:1355-1370. [PubMed: 15672627]

3. Sekhon LH, Fehlings MG. Epidemiology, demographics, and pathophysiology of acute spinal cord injury. Spine. 2001; 26(Suppl. 24):S2-S12. [PubMed: 11805601]

4. Paralysis facts \& figures.. Christopher \& Dana Reeve Foundation Paralysis Resource Center. 2010. [online], http://www.christopherreeve.org/site/c.mtKZKgMwKwG/b.5184189/k.5587/ Paralysis_Facts_Figures.htm

5. Schwab ME. Repairing the injured spinal cord. Science. 2002; 295:1029-1031. [PubMed: 11834824]

6. Park E, Velumian AA, Fehlings MG. The role of excitotoxicity in secondary mechanisms of spinal cord injury: a review with an emphasis on the implications for white matter degeneration. J. Neurotrauma. 2004; 21:754-774. [PubMed: 15253803]

7. Stokes BT, Fox P, Hollinden G. Extracellular calcium activity in the injured spinal cord. Exp. Neurol. 1983; 80:561-572. [PubMed: 6852152]

8. Balentine JD. Spinal cord trauma: in search of the meaning of granular axoplasm and vesicular myelin. J. Neuropathol. Exp. Neurol. 1988; 47:77-92. [PubMed: 3276818]

9. Basso DM, Beattie MS, Bresnahan JC. Graded histological and locomotor outcomes after spinal cord contusion using the NYU weight-drop device versus transection. Exp. Neurol. 1996; 139:244256. [PubMed: 8654527]

10. Kakulas BA. Neuropathology: the foundation for new treatments in spinal cord injury. Spinal Cord. 2004; 42:549-563. [PubMed: 15346131]

11. Liu XZ, et al. Neuronal and glial apoptosis after traumatic spinal cord injury. J. Neurosci. 1997; 17:5395-5406. [PubMed: 9204923]

12. Crowe MJ, Bresnahan JC, Shuman SL, Masters JN, Beattie MS. Apoptosis and delayed degeneration after spinal cord injury in rats and monkeys. Nat. Med. 1997; 3:73-76. [PubMed: 8986744]

13. Emery E, et al. Apoptosis after traumatic human spinal cord injury. J. Neurosurg. 1998; 89:911920. [PubMed: 9833815] 
14. Fawcett JW, Asher RA. The glial scar and central nervous system repair. Brain Res. Bull. 1999; 49:377-391. [PubMed: 10483914]

15. Busch SA, Silver J. The role of extracellular matrix in CNS regeneration. Curr. Opin. Neurobiol. 2007; 17:120-127. [PubMed: 17223033]

16. Zuo J, Neubauer D, Dyess K, Ferguson TA, Muir D. Degradation of chondroitin sulfate proteoglycan enhances the neurite-promoting potential of spinal cord tissue. Exp. Neurol. 1998; 154:654-662. [PubMed: 9878200]

17. Moon LD, Asher RA, Rhodes KE, Fawcett JW. Regeneration of CNS axons back to their target following treatment of adult rat brain with chondroitinase ABC. Nat. Neurosci. 2001; 4:465-466. [PubMed: 11319553]

18. Friedlander DR, et al. The neuronal chondroitin sulfate proteoglycan neurocan binds to the neural cell adhesion molecules Ng-CAM/L1/NILE and N-CAM, and inhibits neuronal adhesion and neurite outgrowth. J. Cell Biol. 1994; 125:669-680. [PubMed: 7513709]

19. Milev P, Maurel P, Haring M, Margolis RK, Margolis RU. TAG-1/axonin-1 is a high-affinity ligand of neurocan, phosphacan/protein-tyrosine phosphatase- $\zeta / \beta$, and N-CAM. J. Biol. Chem. 1996; 271:15716-15723. [PubMed: 8663515]

20. Milev P, et al. Interactions of the chondroitin sulfate proteoglycan phosphacan, the extracellular domain of a receptor-type protein tyrosine phosphatase, with neurons, glia, and neural cell adhesion molecules. J. Cell Biol. 1994; 127:1703-1715. [PubMed: 7528221]

21. Oohira A, Matsui F, Tokita Y, Yamauchi S, Aono S. Molecular interactions of neural chondroitin sulfate proteoglycans in the brain development. Arch. Biochem. Biophys. 2000; 374:24-34. [PubMed: 10640392]

22. Shen Y, et al. PTP $\sigma$ is a receptor for chondroitin sulfate proteoglycan, an inhibitor of neural regeneration. Science. 2009; 326:592-596. [PubMed: 19833921]

23. Menet V, Prieto M, Privat A, Gimenez y Ribotta M. Axonal plasticity and functional recovery after spinal cord injury in mice deficient in both glial fibrillary acidic protein and vimentin genes. Proc. Natl Acad. Sci. USA. 2003; 100:8999-9004. [PubMed: 12861073]

24. Wilhelmsson $U$, et al. Absence of glial fibrillary acidic protein and vimentin prevents hypertrophy of astrocytic processes and improves post-traumatic regeneration. J. Neurosci. 2004; 24:50165021. [PubMed: 15163694]

25. Bradbury EJ, et al. Chondroitinase ABC promotes functional recovery after spinal cord injury. Nature. 2002; 416:636-640. [PubMed: 11948352]

26. Faulkner JR, et al. Reactive astrocytes protect tissue and preserve function after spinal cord injury. J. Neurosci. 2004; 24:2143-2155. [PubMed: 14999065]

27. Herrmann JE, et al. STAT3 is a critical regulator of astrogliosis and scar formation after spinal cord injury. J. Neurosci. 2008; 28:7231-7243. [PubMed: 18614693]

28. Okada S, et al. Conditional ablation of Stat 3 or Socs 3 discloses a dual role for reactive astrocytes after spinal cord injury. Nat. Med. 2006; 12:829-834. [PubMed: 16783372]

29. Sahni V, et al. BMPR1a and BMPR1b signaling exert opposing effects on gliosis after spinal cord injury. J. Neurosci. 2010; 30:1839-1855. [PubMed: 20130193]

30. Blight AR. Macrophages and inflammatory damage in spinal cord injury. J. Neurotrauma. 1992; 9(Suppl. 1):S83-S91. [PubMed: 1588634]

31. Popovich PG, Wei P, Stokes BT. Cellular inflammatory response after spinal cord injury in Sprague-Dawley and Lewis rats. J. Comp. Neurol. 1997; 377:443-464. [PubMed: 8989657]

32. Kreutzberg GW. Microglia: a sensor for pathological events in the CNS. Trends Neurosci. 1996; 19:312-318. [PubMed: 8843599]

33. Beattie MS, et al. ProNGF induces p75-mediated death of oligodendrocytes following spinal cord injury. Neuron. 2002; 36:375-386. [PubMed: 12408842]

34. Filbin MT. Myelin-associated inhibitors of axonal regeneration in the adult mammalian CNS. Nat. Rev. Neurosci. 2003; 4:703-713. [PubMed: 12951563]

35. Rapalino O, et al. Implantation of stimulated homologous macrophages results in partial recovery of paraplegic rats. Nat. Med. 1998; 4:814-821. [PubMed: 9662373] 
36. Enzmann GU, Benton RL, Talbott JF, Cao Q, Whittemore SR. Functional considerations of stem cell transplantation therapy for spinal cord repair. J. Neurotrauma. 2006; 23:479-495. [PubMed: 16629631]

37. Okano H. Stem cell biology of the central nervous system. J. Neurosci. Res. 2002; 69:698-707. [PubMed: 12205662]

38. Parr AM, Tator CH, Keating A. Bone marrow-derived mesenchymal stromal cells for the repair of central nervous system injury. Bone Marrow Transplant. 2007; 40:609-619. [PubMed: 17603514]

39. Sharp J, Keirstead HS. Therapeutic applications of oligodendrocyte precursors derived from human embryonic stem cells. Curr. Opin. Biotechnol. 2007; 18:434-440. [PubMed: 18023336]

40. Louro J, Pearse DD. Stem and progenitor cell therapies: recent progress for spinal cord injury repair. Neurol. Res. 2008; 30:5-16. [PubMed: 18387258]

41. Nandoe Tewarie RS, Hurtado A, Bartels RH, Grotenhuis A, Oudega M. Stem cell-based therapies for spinal cord injury. J. Spinal Cord Med. 2009; 32:105-114. [PubMed: 19569457]

42. Barnabé-Heider F, Frisen J. Stem cells for spinal cord repair. Cell Stem Cell. 2008; 3:16-24. [PubMed: 18593555]

43. McDonald JW, Belegu V. Demyelination and remyelination after spinal cord injury. J. Neurotrauma. 2006; 23:345-359. [PubMed: 16629621]

44. Reier PJ. Cellular transplantation strategies for spinal cord injury and translational neurobiology. NeuroRx. 2004; 1:424-451. [PubMed: 15717046]

45. Johansson CB, et al. Identification of a neural stem cell in the adult mammalian central nervous system. Cell. 1999; 96:25-34. [PubMed: 9989494]

46. Meletis K, et al. Spinal cord injury reveals multilineage differentiation of ependymal cells. PLoS Biol. 2008; 6:e182. [PubMed: 18651793]

47. Friling $\mathrm{S}$, et al. Efficient production of mesencephalic dopamine neurons by Lmx 1a expression in embryonic stem cells. Proc. Natl Acad. Sci. USA. 2009; 106:7613-7618. [PubMed: 19383789]

48. Perrier AL, et al. Derivation of midbrain dopamine neurons from human embryonic stem cells. Proc. Natl Acad. Sci. USA. 2004; 101:12543-12548. [PubMed: 15310843]

49. Wichterle H, Lieberam I, Porter JA, Jessell TM. Directed differentiation of embryonic stem cells into motor neurons. Cell. 2002; 110:385-397. [PubMed: 12176325]

50. Wada T, et al. Highly efficient differentiation and enrichment of spinal motor neurons derived from human and monkey embryonic stem cells. PloS ONE. 2009; 4:e6722. [PubMed: 19701462]

51. Brüstle O, et al. Embryonic stem cell-derived glial precursors: a source of myelinating transplants. Science. 1999; 285:754-756. [PubMed: 10427001]

52. McDonald JW, et al. Transplanted embryonic stem cells survive, differentiate and promote recovery in injured rat spinal cord. Nat. Med. 1999; 5:1410-1412. [PubMed: 10581084]

53. Nistor GI, Totoiu MO, Haque N, Carpenter MK, Keirstead HS. Human embryonic stem cells differentiate into oligodendrocytes in high purity and myelinate after spinal cord transplantation. Glia. 2005; 49:385-396. [PubMed: 15538751]

54. Keirstead HS, et al. Human embryonic stem cell-derived oligodendrocyte progenitor cell transplants remyelinate and restore locomotion after spinal cord injury. J. Neurosci. 2005; 25:4694-4705. [PubMed: 15888645]

55. Sharp J, Frame J, Siegenthaler M, Nistor G, Keirstead HS. Human embryonic stem cell-derived oligodendrocyte progenitor cell transplants improve recovery after cervical spinal cord injury. Stem Cells. 2010; 28:152-163. [PubMed: 19877167]

56. Hofstetter CP, et al. Allodynia limits the usefulness of intraspinal neural stem cell grafts; directed differentiation improves outcome. Nat. Neurosci. 2005; 8:346-353. [PubMed: 15711542]

57. Karimi-Abdolrezaee S, Eftekharpour E, Wang J, Morshead CM, Fehlings MG. Delayed transplantation of adult neural precursor cells promotes remyelination and functional neurological recovery after spinal cord injury. J. Neurosci. 2006; 26:3377-3389. [PubMed: 16571744]

58. Ogawa Y, et al. Transplantation of in vitro-expanded fetal neural progenitor cells results in neurogenesis and functional recovery after spinal cord contusion injury in adult rats. J. Neurosci. Res. 2002; 69:925-933. [PubMed: 12205685] 
59. Pfeifer K, et al. Autologous adult rodent neural progenitor cell transplantation represents a feasible strategy to promote structural repair in the chronically injured spinal cord. Regen. Med. 2006; 1:255-266. [PubMed: 17465808]

60. Han SS, Kang DY, Mujtaba T, Rao MS, Fischer I. Grafted lineage-restricted precursors differentiate exclusively into neurons in the adult spinal cord. Exp. Neurol. 2002; 177:360-375. [PubMed: 12429183]

61. Lepore AC, Fischer I. Lineage-restricted neural precursors survive, migrate, and differentiate following transplantation into the injured adult spinal cord. Exp. Neurol. 2005; 194:230-242. [PubMed: 15899260]

62. Anderson DK, Howland DR, Reier PJ. Fetal neural grafts and repair of the injured spinal cord. Brain Pathol. 1995; 5:451-457. [PubMed: 8974628]

63. Reier PJ, Stokes BT, Thompson FJ, Anderson DK. Fetal cell grafts into resection and contusion/ compression injuries of the rat and cat spinal cord. Exp. Neurol. 1992; 115:177-188. [PubMed: 1370221]

64. Kerr DA, et al. Human embryonic germ cell derivatives facilitate motor recovery of rats with diffuse motor neuron injury. J. Neurosci. 2003; 23:5131-5140. [PubMed: 12832537]

65. Harper JM, et al. Axonal growth of embryonic stem cell-derived motoneurons in vitro and in motoneuron-injured adult rats. Proc. Natl Acad. Sci. USA. 2004; 101:7123-7128. [PubMed: 15118094]

66. Bonner JF, Blesch A, Neuhuber B, Fischer I. Promoting directional axon growth from neural progenitors grafted into the injured spinal cord. J. Neurosci. Res. 2010; 88:1182-1192. [PubMed: 19908250]

67. Cao Q, et al. Functional recovery in traumatic spinal cord injury after transplantation of multineurotrophin-expressing glial-restricted precursor cells. J. Neurosci. 2005; 25:6947-6957. [PubMed: 16049170]

68. Davies JE, et al. Transplanted astrocytes derived from BMP- or CNTF-treated glial-restricted precursors have opposite effects on recovery and allodynia after spinal cord injury. J. Biol. 2008; 7:24. [PubMed: 18803859]

69. Syková E, et al. Autologous bone marrow transplantation in patients with subacute and chronic spinal cord injury. Cell Transplant. 2006; 15:675-687. [PubMed: 17269439]

70. Kopen GC, Prockop DJ, Phinney DG. Marrow stromal cells migrate throughout forebrain and cerebellum, and they differentiate into astrocytes after injection into neonatal mouse brains. Proc. Natl Acad. Sci. USA. 1999; 96:10711-10716. [PubMed: 10485891]

71. Eglitis MA, Mezey E. Hematopoietic cells differentiate into both microglia and macroglia in the brains of adult mice. Proc. Natl Acad. Sci. USA. 1997; 94:4080-4085. [PubMed: 9108108]

72. Liu Y, Rao MS. Transdifferentiation—fact or artifact. J. Cell Biochem. 2003; 88:29-40. [PubMed: 12461772]

73. Mori F, Himes BT, Kowada M, Murray M, Tessler A. Fetal spinal cord transplants rescue some axotomized rubrospinal neurons from retrograde cell death in adult rats. Exp. Neurol. 1997; 143:45-60. [PubMed: 9000445]

74. Tang BL, Low CB. Genetic manipulation of neural stem cells for transplantation into the injured spinal cord. Cell. Mol. Neurobiol. 2007; 27:75-85. [PubMed: 17151948]

75. Tobias CA, et al. Delayed grafting of BDNF and NT-3 producing fibroblasts into the injured spinal cord stimulates sprouting, partially rescues axotomized red nucleus neurons from loss and atrophy, and provides limited regeneration. Exp. Neurol. 2003; 184:97-113. [PubMed: 14637084]

76. Schwab ME, Bartholdi D. Degeneration and regeneration of axons in the lesioned spinal cord. Physiol. Rev. 1996; 76:319-370. [PubMed: 8618960]

77. Richardson PM, McGuinness UM, Aguayo AJ. Axons from CNS neurons regenerate into PNS grafts. Nature. 1980; 284:264-265. [PubMed: 7360259]

78. Houle JD. Demonstration of the potential for chronically injured neurons to regenerate axons into intraspinal peripheral nerve grafts. Exp. Neurol. 1991; 113:1-9. [PubMed: 2044676]

79. Levi AD, et al. Peripheral nerve grafts promoting central nervous system regeneration after spinal cord injury in the primate. J. Neurosurgery. 2002; 96:197-205. 
80. Silver J, Miller JH. Regeneration beyond the glial scar. Nat. Rev. Neurosci. 2004; 5:146-156. [PubMed: 14735117]

81. Chen A, Xu XM, Kleitman N, Bunge MB. Methylprednisolone administration improves axonal regeneration into Schwann cell grafts in transected adult rat thoracic spinal cord. Exp. Neurol. 1996; 138:261-276. [PubMed: 8620925]

82. Paino CL, Bunge MB. Induction of axon growth into Schwann cell implants grafted into lesioned adult rat spinal cord. Exp. Neurol. 1991; 114:254-257. [PubMed: 1748200]

83. Ramón-Cueto A, Plant GW, Avila J, Bunge MB. Long-distance axonal regeneration in the transected adult rat spinal cord is promoted by olfactory ensheathing glia transplants. J. Neurosci. 1998; 18:3803-3815. [PubMed: 9570810]

84. Féron F, et al. Autologous olfactory ensheathing cell transplantation in human spinal cord injury. Brain. 2005; 128:2951-2960. [PubMed: 16219671]

85. Saberi H, et al. Treatment of chronic thoracic spinal cord injury patients with autologous Schwann cell transplantation: an interim report on safety considerations and possible outcomes. Neurosci. Lett. 2008; 443:46-50. [PubMed: 18662744]

86. Hofstetter CP, et al. Marrow stromal cells form guiding strands in the injured spinal cord and promote recovery. Proc. Natl Acad. Sci. USA. 2002; 99:2199-2204. [PubMed: 11854516]

87. Gu W, et al. Transplantation of bone marrow mesenchymal stem cells reduces lesion volume and induces axonal regrowth of injured spinal cord. Neuropathology. doi:10.1111/j. 1440-1789.2009.01063.x.

88. Jin Y, Fischer I, Tessler A, Houle JD. Transplants of fibroblasts genetically modified to express BDNF promote axonal regeneration from supraspinal neurons following chronic spinal cord injury. Exp. Neurol. 2002; 177:265-275. [PubMed: 12429228]

89. Liu Y, et al. Transplants of fibroblasts genetically modified to express BDNF promote regeneration of adult rat rubrospinal axons and recovery of forelimb function. J. Neurosci. 1999; 19:4370-4387. [PubMed: 10341240]

90. Taylor L, Jones L, Tuszynski MH, Blesch A. Neurotrophin-3 gradients established by lentiviral gene delivery promote short-distance axonal bridging beyond cellular grafts in the injured spinal cord. J. Neurosci. 2006; 26:9713-9721. [PubMed: 16988042]

91. Lu P, Yang H, Jones LL, Filbin MT, Tuszynski MH. Combinatorial therapy with neurotrophins and cAMP promotes axonal regeneration beyond sites of spinal cord injury. J. Neurosci. 2004; 24:6402-6409. [PubMed: 15254096]

92. Bregman BS, et al. Transplants and neurotrophic factors increase regeneration and recovery of function after spinal cord injury. Prog. Brain Res. 2002; 137:257-273. [PubMed: 12440372]

93. Kadoya $\mathrm{K}$, et al. Combined intrinsic and extrinsic neuronal mechanisms facilitate bridging axonal regeneration one year after spinal cord injury. Neuron. 2009; 64:165-172. [PubMed: 19874785]

94. Tator $\mathrm{CH}$. Review of treatment trials in human spinal cord injury: issues, difficulties, and recommendations. Neurosurgery. 2006; 59:957-982. [PubMed: 17143232]

95. Steeves JD, et al. Guidelines for the conduct of clinical trials for spinal cord injury (SCI) as developed by the ICCP panel: clinical trial outcome measures. Spinal Cord. 2007; 45:206-221. [PubMed: 17179972]

96. Fawcett JW, et al. Guidelines for the conduct of clinical trials for spinal cord injury as developed by the ICCP panel: spontaneous recovery after spinal cord injury and statistical power needed for therapeutic clinical trials. Spinal Cord. 2007; 45:190-205. [PubMed: 17179973]

97. Lammertse D, et al. Guidelines for the conduct of clinical trials for spinal cord injury as developed by the ICCP panel: clinical trial design. Spinal Cord. 2007; 45:232-242. [PubMed: 17179970]

98. Tuszynski MH, et al. Guidelines for the conduct of clinical trials for spinal cord injury as developed by the ICCP Panel: clinical trial inclusion/exclusion criteria and ethics. Spinal Cord. 2007; 45:222-231. [PubMed: 17179971]

99. Magnus T, Liu Y, Parker GC, Rao MS. Stem cell myths. Philos. Trans. R. Soc. Lond. B Biol. Sci. 2008; 363:9-22. [PubMed: 17284414]

100. Blight A, et al. Position statement on the sale of unproven cellular therapies for spinal cord injury: the international campaign for cures of spinal cord injury paralysis. Spinal Cord. 2009; 47:713714. [PubMed: 19417762] 
101. Hawryluk GW, Rowland J, Kwon BK, Fehlings MG. Protection and repair of the injured spinal cord: a review of completed, ongoing, and planned clinical trials for acute spinal cord injury. Neurosurg. Focus. 2008; 25:E14. [PubMed: 18980474]

102. Knafo S, Choi D. Clinical studies in spinal cord injury: moving towards successful trials. Br. J. Neurosurg. 2008; 22:3-12. [PubMed: 18224516]

103. Geffner LF, et al. Administration of autologous bone marrow stem cells into spinal cord injury patients via multiple routes is safe and improves their quality of life: comprehensive case studies. Cell Transplant. 2008; 17:1277-1293. [PubMed: 19364066]

104. Pal R, et al. Ex vivo-expanded autologous bone marrow-derived mesenchymal stromal cells in human spinal cord injury/paraplegia: a pilot clinical study. Cytotherapy. 2009; 11:897-911. [PubMed: 19903102]

105. Yoon SH, et al. Complete spinal cord injury treatment using autologous bone marrow cell transplantation and bone marrow stimulation with granulocyte macrophage-colony stimulating factor: phase I/II clinical trial. Stem Cells. 2007; 25:2066-2073. [PubMed: 17464087]

106. Mackay-Sim A, et al. Autologous olfactory ensheathing cell transplantation in human paraplegia: a 3-year clinical trial. Brain. 2008; 131:2376-2386. [PubMed: 18689435]

107. Lima C, et al. Olfactory mucosal autografts and rehabilitation for chronic traumatic spinal cord injury. Neurorehabil. Neural Repair. 2010; 24:10-22. [PubMed: 19794133]

108. Knoller N, et al. Clinical experience using incubated autologous macrophages as a treatment for complete spinal cord injury: phase I study results. J. Neurosurg. Spine. 2005; 3:173-181. [PubMed: 16235699]

109. Moviglia GA, et al. Combined protocol of cell therapy for chronic spinal cord injury. Report on the electrical and functional recovery of two patients. Cytotherapy. 2006; 8:202-209. [PubMed: 16793729]

110. Lithium and blood cord cell for spinal cord injury.. Chinese Spinal Cord Injury Network. 2007. [online], http://www.chinascinet.org/index.php? option=com_content\&task=view\&id=31\&Itemid=57

111. Spinal Cord Injury Network USA. 2009. [online], http://www.scinetusa.org/

112. Alper J. Geron gets green light for human trial of ES cell-derived product. Nat. Biotechnol. 2009; 27:213-214. [PubMed: 19270655]

113. Couzin J. Biotechnology. Celebration and concern over US trial of embryonic stem cells. Science. 2009; 323:568. [PubMed: 19179496]

114. Horner PJ, et al. Proliferation and differentiation of progenitor cells throughout the intact adult rat spinal cord. J. Neurosci. 2000; 20:2218-2228. [PubMed: 10704497]

115. Horky LL, Galimi F, Gage FH, Horner PJ. Fate of endogenous stem/progenitor cells following spinal cord injury. J. Comp. Neurol. 2006; 498:525-538. [PubMed: 16874803]

116. Mothe AJ, Tator $\mathrm{CH}$. Proliferation, migration, and differentiation of endogenous ependymal region stem/progenitor cells following minimal spinal cord injury in the adult rat. Neuroscience. 2005; 131:177-187. [PubMed: 15680701]

117. Kitada M, Chakrabortty S, Matsumoto N, Taketomi M, Ide C. Differentiation of choroid plexus ependymal cells into astrocytes after grafting into the pre-lesioned spinal cord in mice. Glia. 2001; 36:364-374. [PubMed: 11746773]

118. Cao QL, Howard RM, Dennison JB, Whittemore SR. Differentiation of engrafted neuronalrestricted precursor cells is inhibited in the traumatically injured spinal cord. Exp. Neurol. 2002; 177:349-359. [PubMed: 12429182]

119. Yang H, et al. Endogenous neurogenesis replaces oligodendrocytes and astrocytes after primate spinal cord injury. J. Neurosci. 2006; 26:2157-2166. [PubMed: 16495442]

120. Pearse DD, Bunge MB. Designing cell- and gene-based regeneration strategies to repair the injured spinal cord. J. Neurotrauma. 2006; 23:438-452. [PubMed: 16629628]

121. Ohori Y, et al. Growth factor treatment and genetic manipulation stimulate neurogenesis and oligodendrogenesis by endogenous neural progenitors in the injured adult spinal cord. J. Neurosci. 2006; 26:11948-11960. [PubMed: 17108169]

122. Takahashi K, Yamanaka S. Induction of pluripotent stem cells from mouse embryonic and adult fibroblast cultures by defined factors. Cell. 2006; 126:663-676. [PubMed: 16904174] 
123. Takahashi K, et al. Induction of pluripotent stem cells from adult human fibroblasts by defined factors. Cell. 2007; 131:861-872. [PubMed: 18035408]

124. Nakagawa M, et al. Generation of induced pluripotent stem cells without Myc from mouse and human fibroblasts. Nat. Biotechnol. 2008; 26:101-106. [PubMed: 18059259]

125. Yu J, et al. Induced pluripotent stem cell lines derived from human somatic cells. Science. 2007; 318:1917-1920. [PubMed: 18029452]

126. Kim D, et al. Generation of human induced pluripotent stem cells by direct delivery of reprogramming proteins. Cell Stem Cell. 2009; 4:472-476. [PubMed: 19481515]

127. Feng Q, et al. Hemangioblastic derivatives from human induced pluripotent stem cells exhibit limited expansion and early senescence. Stem Cells. 2010; 28:704-712. [PubMed: 20155819]

128. Robbins RD, Prasain N, Maier BF, Yoder MC, Mirmira RG. Inducible pluripotent stem cells: not quite ready for prime time? Curr. Opin. Organ Transplant. 2009; 15:61-67. [PubMed: 19855280]

129. Bulte JW. In vivo MRI cell tracking: clinical studies. AJR Am. J. Roentgenol. 2009; 193:314325. [PubMed: 19620426] 


\section{Key points}

Strategies for the therapeutic use of stem cells and their derivatives in spinal cord injury (SCI) include cell replacement, trophic support and facilitation of axon regeneration

Stem cell transplantation, either alone or in combination with other treatments, has produced functional improvements in animal models of SCI

Caution must be exercised when evaluating the successes of stem cell therapy for SCI, and when developing these therapies for appropriate clinical trials

The existing data from clinical trials have shown some stem cell transplants to be safe, but with very limited or no therapeutic efficacy

Future strategies for stem cell therapies include the use of induced pluripotent stem cells, as well as the modulation of endogenous progenitor cell populations 


\section{Box 1 | Important considerations in transplantation therapy}

Ethics

Clinical trials should calculate the associated risks of any experimental therapy and include treatments with potential for success

\section{Circuitry differences}

The rodent locomotor system is far less dependent on corticospinal input than primate and human systems - an important consideration when evaluating potential treatment strategies or setting outcome measures

\section{Injury models}

Most cell transplantation approaches have been tested in animal models with mild to moderate injuries

Type of animal model of injury and time of transplantation are important factors in determining appropriate participants for clinical trials

Host environment for transplanted cells can vary considerably; for example, transection or knife injuries that disrupt the meninges have different cellular constituents in the lesion site from crush lesions in which the dura is spared

\section{Severity of spinal cord injury}

Level and severity of spinal cord injury are important criteria for inclusion in clinical trials; for example, strategies using trophic support of spared tissue or remyelination of spared axons are best suited for trials in patients with incomplete injury

Cervical injuries are more common than thoracic or lumbar injuries, but errors in treatment of cervical injuries can be far more devastating

\section{Measures of recovery}

High rates of spontaneous recovery in moderate and incomplete injuries complicate assessment of efficacy of intervention in these cases

Parameters to assess treatment efficacy can include clinical assessment scales, and imaging and neurophysiological outcomes

\section{Proliferation potential}

Stem cells and their derivatives carry a risk of tumor growth after transplantation

\section{Neuropathic pain}

Misguided incorporation of transplants into circuitry can result in neuropathic pain, which can potentially be reduced using genetic approaches

\section{Tracking transplanted cells}

Current imaging techniques have insufficient resolution to track transplanted cells

Cells can be prelabeled for imaging, and clinical trials are underway to test this approach for clinical use ${ }^{129}$ 


\section{Review criteria}

The PubMed database was searched using Entrez for articles published up to 31 March 2010. Search terms included: "spinal cord injury therapy", "glial scar", "neural progenitor", "transplantation spinal cord", "clinical trials spinal cord injury" and "spinal cord regeneration". Full articles were obtained and references were checked for additional material when appropriate. 


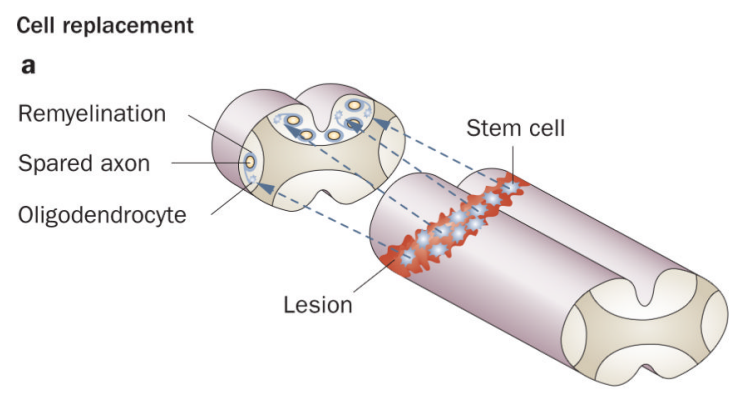

b

Neuroprotection and trophic support

C
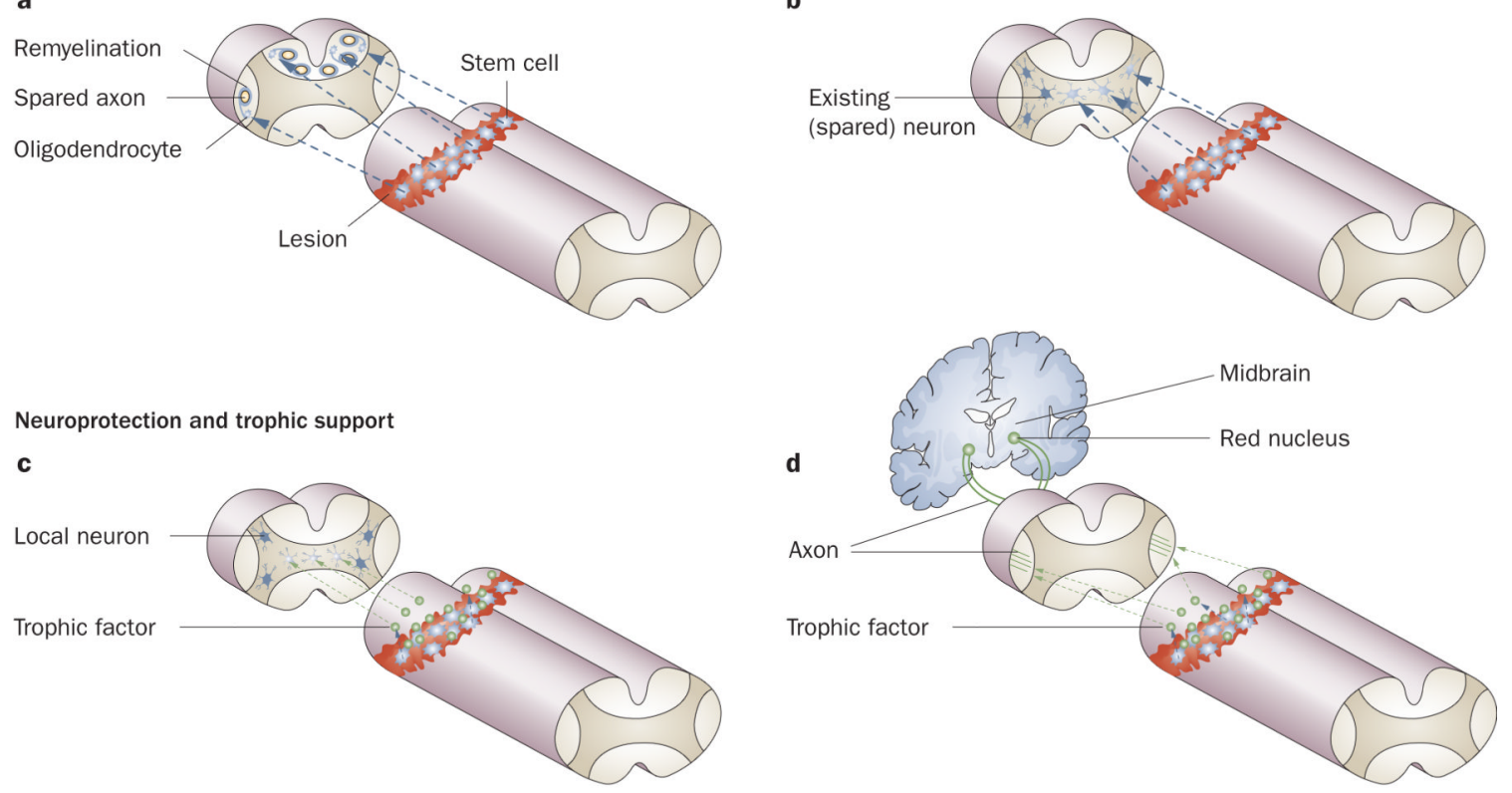

Facilitating axon outgrowth

e

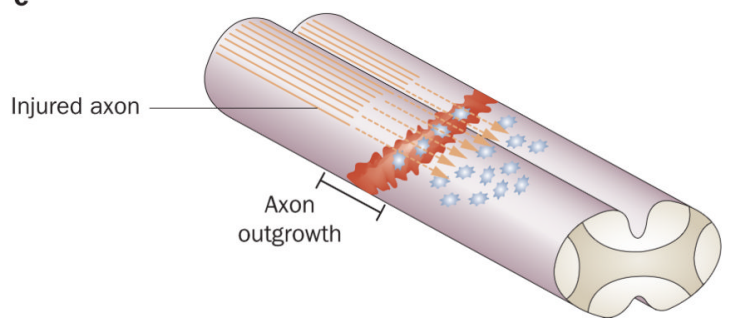

f

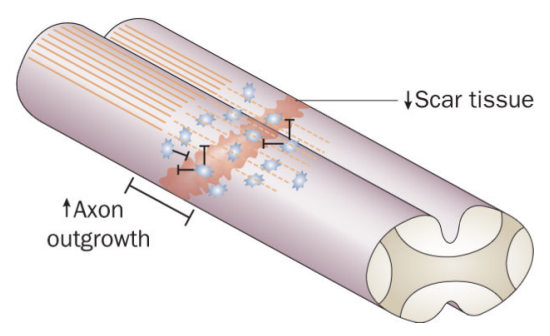

Figure 1.

Rationales for stem cell transplantation in spinal cord injury repair. a,b | Stem cells can be directed to differentiate into specific lineages to replace lost or damaged cells (cell replacement). The cells can be directed to differentiate into oligodendrocytes, which can remyelinate spared axons (panel a), or into neurons to replenish the existing damaged neurons (panel b). c,d $\mid$ Stem cells can be engineered to produce trophic factors that can promote survival and prevent death of damaged cells (trophic support). These trophic factors can be directed towards local cells in the area surrounding the spinal cord lesion (panel c) or directed to provide trophic support (green arrows) to neurons with axons that project down the spinal cord (panel d), such as neurons in the red nucleus in the midbrain, the axons of which project down the spinal cord as the rubrospinal tract. e,f $\mid$ Stem cells can facilitate axon outgrowth. The cells can be transplanted directly into and adjacent to the lesion, which promotes axon growth and extension past the lesion (panel e). Stem cell transplants can also be designed to diminish and/or inhibit the scar tissue in the lesion, thereby reducing its inhibitory effects and promoting axon outgrowth (panel f). 
Table 1

Results of clinical trials using stem cell therapy in patients with spinal cord injury

\begin{tabular}{|c|c|c|c|c|c|}
\hline Study & Number of patients & $\begin{array}{l}\text { Time of } \\
\text { transplant after } \\
\text { injury }\end{array}$ & Cell type & $\begin{array}{l}\text { Route of cell } \\
\text { delivery }\end{array}$ & Comments \\
\hline $\begin{array}{l}\text { Feron et al. } \\
(2005)^{84}\end{array}$ & 3 (aged 18-55 years) & 6-32 months & $\begin{array}{l}\text { Autologous olfactory } \\
\text { ensheathing cells }\end{array}$ & Into lesion & $\begin{array}{l}\text { No complications and no } \\
\text { efficacy after } 1 \text { year; same } \\
\text { result } 3 \text { years after } \\
\text { transplantation }^{95}\end{array}$ \\
\hline $\begin{array}{l}\text { Geffner et } \\
\text { al. } \\
(2008)^{103}\end{array}$ & $\begin{array}{l}4 \text { acute (aged } 28-33 \\
\text { years) and } 4 \text { chronic } \\
\text { (aged } 27-44 \text { years) }\end{array}$ & $\begin{array}{l}\text { Acute: between } 5 \\
\text { days and } 6 \\
\text { months; chronic: } \\
\text { 5-21 years }\end{array}$ & $\begin{array}{l}\text { Autologous bone marrow } \\
\text { stem cells }\end{array}$ & $\begin{array}{l}\text { Spinal cord, } \\
\text { spinal canal and } \\
\text { intravenous }\end{array}$ & $\begin{array}{l}\text { No tumors or pain; } \\
\text { improvement in quality of } \\
\text { life and bladder function }\end{array}$ \\
\hline $\begin{array}{l}\text { Knoller et } \\
\text { al. } \\
(2005)^{108}\end{array}$ & 8 (aged $18-35$ years) & $\begin{array}{l}\text { Within } 15 \text { days of } \\
\text { injury }\end{array}$ & $\begin{array}{l}\text { Incubated autologous } \\
\text { macrophages (ProCord } \\
\text { cells) }\end{array}$ & $\begin{array}{l}\text { Microinjected } \\
\text { into caudal edge } \\
\text { of lesion }\end{array}$ & $\begin{array}{l}\text { Phase I trial showed some } \\
\text { efficacy in } 3 \text { patients; phase } \\
\text { II trial was abandoned after } \\
1 \text { year }\end{array}$ \\
\hline $\begin{array}{l}\text { Lima et al. } \\
(2010)^{107}\end{array}$ & 20 (aged 18-37 years) & 18-189 months & Olfactory mucosal cells & $\begin{array}{l}\text { Into lesion (after } \\
\text { partial scar } \\
\text { removal) }\end{array}$ & $\begin{array}{l}\text { Improvement in ASIA } \\
\text { motor scores; mean follow- } \\
\text { up } 27.7 \text { months; } \\
\text { improvement in } 11 \text { patients } \\
\text { and deterioration in } 1 \\
\text { patient }\end{array}$ \\
\hline $\begin{array}{l}\text { Moviglia et } \\
\text { al. } \\
(2006)^{109}\end{array}$ & 2 (aged 19 and 21 years) & $\begin{array}{l}8 \text { months and } 2.5 \\
\text { years }\end{array}$ & T cells and MSCs & $\begin{array}{l}\text { Intravenous ( } \mathrm{T} \\
\text { cells) or via a } \\
\text { feeding artery } \\
\text { (MSCs) }\end{array}$ & $\begin{array}{l}\text { Patients had thoracic or } \\
\text { cervical injury; combined } \\
\text { cell transplantation with } \\
\text { neurorehabilitation; both } \\
\text { patients showed sensory } \\
\text { improvement }\end{array}$ \\
\hline $\begin{array}{l}\text { Saberi et } \\
\text { al. }(2008)^{85}\end{array}$ & 4 (aged 22-43 years) & $28-80$ months & $\begin{array}{l}\text { Schwann cells from sural } \\
\text { nerve }\end{array}$ & Into lesion & $\begin{array}{l}\text { No adverse effects reported; } \\
\text { not an efficacy study }\end{array}$ \\
\hline $\begin{array}{l}\text { Syková et } \\
\text { al. }(2006)^{69}\end{array}$ & 20 (aged 19-41 years) & $\begin{array}{l}\text { Acute }(n=7): 10- \\
30 \text { days; chronic } \\
(n=13): 2-17 \\
\text { months }\end{array}$ & Autologous bone marrow & $\begin{array}{l}\text { Intra-arterial }(n \\
=6) \text { or } \\
\text { intravenous }(n= \\
14)\end{array}$ & $\begin{array}{l}\text { No complications reported } \\
\text { up to } 1 \text { year after transplant; } \\
5 \text { of the patients who } \\
\text { received cells intra- } \\
\text { arterially showed } \\
\text { improvement; only } 1 \text { patient } \\
\text { with chronic SCI reported } \\
\text { improvement }\end{array}$ \\
\hline $\begin{array}{l}\text { Yoon et al. } \\
(2007)^{105}\end{array}$ & $\begin{array}{l}17 \text { acute (aged } 28-52 \\
\text { years), } 6 \text { subacute (aged } \\
15-43 \text { years) and } 12 \\
\text { chronic (aged } 27-57 \\
\text { years }\end{array}$ & $\begin{array}{l}\text { Acute: }<2 \text { weeks; } \\
\text { subacute: } 2-8 \\
\text { weeks; chronic: } \\
>8 \text { weeks }\end{array}$ & Bone marrow cells & $\begin{array}{l}\text { Into cord around } \\
\text { lesion }\end{array}$ & $\begin{array}{l}\text { ASIA grade improved } \\
30.4 \% \text { in patients with acute } \\
\text { or subacute SCI, but no } \\
\text { improvement in chronic } \\
\text { treatment group }\end{array}$ \\
\hline
\end{tabular}

Abbreviations: ASIA, American Spinal Injury Association; MSCs, marrow stromal cells; SCI, spinal cord injury. 